\title{
The Limits of Judicial Fidelity to Law: The Coxford Lecture
}

\author{
Jeffrey Goldsworthy
}

\section{Introduction}

In this lecture I question my own legalist inclinations, and ask whether judges might sometimes be morally justified in indulging in covert law-breaking - whether some measure of judicial subterfuge might be desirable - because it enhances the rule of law, justice or good governance. A plausible argument can be made that judges engage in subterfuge more frequently than we tend to think, and are justified in doing so. My attempt to explore these issues is not an exercise in judge-bashing, and I sincerely hope that no judge will construe it in that way.

Early this year, the High Court of Australia in a case called Kirk ${ }^{1}$ made a radical change to constitutional arrangements in that country. It held that state Parliaments could not validly enact a privative or ouster clause preventing a state Supreme Court from reviewing the decisions of inferior courts (and also, presumably, administrative agencies) for jurisdictional error. The case arguably involved an injustice to an individual that the courts could not remedy had the privative clause in question been effective.

Until this decision, it had been universally assumed that state Parliaments could validly enact privative clauses, and in many previous cases courts considered how to interpret them, without ever suggesting that they might be invalid. ${ }^{2}$

The Court's reasoning on this point is very brief - indeed, perfunctory —and is widely regarded as quite implausible. It purported to rely on originalist reasoning. It fixed on a provision of the Australian Constitution (s.73) that provides for appeals from state Supreme Courts to the High Court, and reasoned that in 1900, when the Constitution was enacted, it was an essential characteristic of the very concept of a state Supreme Court that it had authority to review judicial and administrative decisions and correct jurisdictional errors. ${ }^{3}$ Any law removing or restricting that authority would therefore be inconsistent with the very meaning of the words "Supreme Court" in the Constitution. This is not plausible because no-one had ever before adverted to this supposed conceptual truth — neither in or around 1900, nor subsequently — even though numerous privative clauses had been enacted and judicially considered. In Kirk, the High Court asks us to believe that all these privative clauses were inconsistent with a concept central to the constitutional thought of

I thank Mr Steven Coxford for so generously enabling the University of Western Ontario Law School to host this lecture series, and Grant Huscroft for the great honour of inviting me to give the 2010 lecture, now revised and enlarged.

1. Kirk v Industrial Relations Commission of NSW (2010) 239 CLR 531

2. See M Aronson, B Dyer \& M Groves, Judicial Review of Administrative Action, 4th ed (Sydney, AU: Lawbook Co, 2009) at ch 17.

3. Supra note 1 at 580-81. 
legislators, lawyers and judges in the year 1900, even though none of them noticed it. The Court is claiming that, 110 years later, it has arrived at a more accurate understanding of their concepts than they themselves possessed.

Most judges and lawyers strongly disapprove of privative clauses, because they believe that the rule of law requires every power possessed by government officials to be subject to legal limits enforceable by an independent judiciary. On the other hand, within Britain itself, the doctrine of parliamentary sovereignty allowed Parliament to enact privative clauses to exclude judicial review, and the constitutions of British colonies conferred a similar plenary power on colonial and dominion legislatures. ${ }^{4}$ The perceived conflict between the principles of the rule of law, and of legislative supremacy, was resolved by judges interpreting privative clauses as narrowly as they possibly could - indeed, sometimes interpreting them almost out of existence. I will return to this later. ${ }^{5}$

The decision in Kirk escalates judicial resistance to privative clauses in Australia to a new level. By declaring them to be (for the most part ${ }^{6}$ ) constitutionally invalid, it makes redundant the previous strategy of interpretive ingenuity. The decision has been praised for strengthening the rule of law in Australia. ${ }^{7}$ But what if the decision involved, as I suspect it did, a deliberate change to the Constitution rather flimsily disguised as an interpretation of it? The High Court would then have violated s.128 of the Constitution, which states that it can only be changed by Parliament with the assent of the electorate in a referendum. As a former Chief Justice once said, it is the duty of the Court not to interfere with the other branches of government unless the Constitution requires it to: "Otherwise the interference of the Court ... is an unwarrantable intrusion and a breach of law as great as any it assumes to correct."

If a court violates the law it breaches the rule of law, and this includes changing laws that it has no authority to change. Yet just as a violation of one human right might enhance the protection of human rights overall (which a "utilitarian of rights" would recommend), ${ }^{9}$ so too a one-off violation of the rule of law might advance the cause of justice or good government, or even strengthen the rule of law in other respects and overall. This quasi-paradox is the topic of this lecture.

Some may find it grating or even offensive to hear talk about judges violating the law, and concealing the violation with an untruth. But it is important that this phenomenon be acknowledged and debated. I will refer to noble lies, fig leaves, wishful thinking and sloppy thinking. I find this just as unsettling as anyone, because I myself incline towards a fairly strict legalism. Here is what I said in print ten years ago:

4. J Goldsworthy, The Sovereignty of Parliament, History and Philosophy (Oxford: Clarendon Press, 1999); G Carney, The Constitutional Systems of the Australian States and Territories (Cambridge: Cambridge University Press, 2006) at 106-07.

5. See text to notes $45-48$ and $82-83$ below.

6. Privative clauses at the federal level purporting to exclude High Court review for jurisdictional error had previously been held to be unconstitutional, but on a much sounder basis in the constitutional text: see Plaintiff S157 v Commonwealth (2003) 211 CLR 476.

7. S Ratnapala, "Rule of Law Ruling Widens Separation of Powers", The Australian (12 February 2010).

8. King v Hibble; Ex p Broken Hill Proprietary Co Ltd (1920) 28 CLR 456, 469 per Isaacs J.

9. R Nozick, Anarchy, State and Utopia (New York: Basic Books, 1974) at 28-29. 
Modern judges are prone to solemnly invoke 'the Rule of Law' to justify inventing or expanding limits to the authority of other governmental institutions. They should reflect on the fact that they too are subject to the rule of law and that, ultimately, the only practical mechanism for ensuring that they abide by it is their own scrupulous intellectual honesty. If that cannot be trusted, the rule of law is in peril. ${ }^{10}$

As I said at the start, my intention is to question my own inclinations. Those involved in the administration of the law understandably aspire to "happy endings": practical outcomes that promote justice and the common good. ${ }^{11}$ This has produced a perennial tension in legal thought between, on the one hand, strict adherence to legal norms and their logical implications, and on the other hand, the entirely understandable urge to "do justice" — as the judges see it - to the flesh and blood individuals who stand before them. How do judges, and how should they, resolve that tension?

\section{Some Qualifications}

Let me clear up some possible distractions. We all know that there are "hard cases" where the law is to some extent indeterminate, as when it is ambiguous, vague, inconsistent, insufficiently explicit or even silent as to issues that judges must resolve. Judges must resolve disputes properly brought before them, and when the law does not resolve them, they must act creatively and make new law, guided by political morality. ${ }^{12}$ I am well aware of this, but not concerned with it at the moment. I am not concerned with judges filling in gaps left open by indeterminate law. I am concerned with judges allowing extra-legal considerations to over-ride determinate law.

Of course, one way that judges can over-ride determinate law is to pretend that it is indeterminate and leaves them legitimate scope for creativity. But they rarely do that, partly because they are usually reluctant to admit that they have any lawmaking discretion at all. In an article titled "Judges as Liars", the political scientist Martin Shapiro argues that judges everywhere tend to attribute their decisions to pre-existing law, even when they have to make new law because of legal indeterminacy. This is supposedly because losing parties are more likely to accept adverse decisions if persuaded that they were mandated by law. Shapiro concludes his article by saying "Judges necessarily lie because that is the nature of the activity they engage in."13 Others have put the same point less provocatively. John Austin said that "the fictions through which judges innovate on existing law, may be likened to those conventional, and not incommodious lies, through which the intercourse

10. J Goldsworthy, “The Preamble, Judicial Independence and Judicial Integrity” (2000) 11 Constitutional Commentary 60 at 64.

11. I am indebted for the "happy endings" metaphor to S Levinson, "Bush v Gore and the French Revolution" (2002) 65 Law \& Contemp Prob 7 at 11.

12. There is a massive literature on this: a good place to start is HLA Hart, The Concept of Law (Oxford: Oxford University Press, 1961) at ch VII, and R Dworkin, Taking Rights Seriously (Cambridge, MA: Harvard University Press,1977) at ch 4.

13. M Shapiro, "Judges as Liars" (1994) 17 Harv J L \& Pub Pol'y 155 at 156. 
of polished society is habitually carried on."'14 In a book defending judicial creativity, former Australian High Court Justice Michael Kirby claims that "judges of the English tradition ... [n] early all practised the 'noble lie' of 'strict and complete legalism'." ${ }^{15}$ His book is scattered with references to this as a "noble lie", "fiction", "pretence" or "illusionism". ${ }^{16}$

Another big issue that I need to set aside concerns the common law. Where common law is concerned, the highest appellate court is legally authorised to override pre-existing legal norms if it regards them as so unjust that the countervailing reasons for adhering to precedent are outweighed. This does not raise the kind of conflict or dilemma that I want to explore now, which generally concerns constitutions or statutes that judges have no lawful authority to amend. Some scholars argue that judges do have lawful authority to change statutes and constitutions, presumably based on the fact that sometimes judges have, in fact, changed them. ${ }^{17}$ A major difficulty for such arguments is that judges rarely, if ever, claim to have such authority. Even when an "interpretation" of a statute seems extraordinarily creative, judges purport to be merely clarifying its true meaning. ${ }^{18} \mathrm{I}$ acknowledgeand indeed will argue later - that this is sometimes a pretence. Joseph Raz is therefore right to say that "not infrequently, what judges say is one thing and what they do is another." 19 But what judges say they do is much better evidence of the scope of their lawful authority than what they might sometimes actually do. Any claim about their lawful authority must be able to pass the test of public candour: if that claim is not and cannot be candidly asserted in public by them, it is surely false. How can judges possess a legal authority that they dare not publicly assert, and feel compelled to keep secret?

I also want to emphasise that in what follows, I am not presuming the truth of some version of legal positivism, which regards law as ultimately a matter of fact and not of morality. Non-positivist theories maintain that establishing what the law is depends partly on considerations of justice as well as matters of fact. But no legal theorist maintains that law, and justice, are one and the same- that the law always is whatever it morally ought to be, regardless of facts about what norms have been enacted or accepted as binding. That is why the most eminent non-positivist, Ronald Dworkin, acknowledges that on rare occasions the law might be so unjust that even judges morally ought to disobey it. ${ }^{20}$ It is true, however, that compared with their positivist colleagues, non-positivist judges would probably encounter fewer occasions in which they perceive a conflict between the demands of law and of morality.

14. J Austin, Lectures on Jurisprudence, 5th ed (London: John Murray, 1885) vol II at 610.

15. The Hon M Kirby, Judicial Activism (London: Sweet \& Maxwell, 2004) at 46.

16. Ibid at 6, 11, 28-29, 35, 52, 61, 69 passim.

17. E.g., J Raz, "On the Authority and Interpretation of Constitutions: Some Preliminaries" in L Alexander, ed, Constitutionalism: Philosophical Foundations (Cambridge: Cambridge University Press, 1999) at 177 and 185, discussed in J Goldsworthy, "Raz on Constitutional Interpretation" (2003) 22 Law \& Phil 167.

18. Ibid at 176 .

19. Raz, supra note 17 at 177.

20. R Dworkin, Justice in Robes (Cambridge, MA: Harvard University Press, 2006) at 18-19. 
Australia does not have a Bill or Charter of Rights. ${ }^{21}$ My theme may be less relevant in jurisdictions that do have one, because it gives judges much more power to avoid unjust results without having to engage in subterfuge, by expressly authorising the creative interpretation or even invalidation of statutes. But experience, especially in the United States, shows that a Bill of Rights does not remedy everything that a judge might consider grossly unjust - its scope, as Grant Huscroft has usefully put it, is "finite" 22 _and so my theme should still have some resonance outside Australia.

\section{Methodological Difficulties}

My theme concerns judges engaging in subterfuge to achieve worthy goals. Whether a judge has done this is very difficult to establish, for several reasons. First, it is always possible that the judge simply got the law wrong, perhaps as a result of muddled thinking. Secondly, it is possible for judges to engage in "wishful thinking", and delude themselves. All of us, when we are strongly attracted to a particular conclusion, are sorely tempted to evaluate argument and evidence selectively, and bend or stretch logic, in order to reach it. Justice Cardozo said that judges who innovate tend "to disguise the innovation even from themselves, and to announce in all sincerity that it was all as it had been before." ${ }^{23}$ Indeed, self-deception was Jerome Frank's explanation for what he saw as the systematic failure of judges to acknowledge their law-making role. ${ }^{24}$ Thirdly, some judges seem to be guided by an inner certainty that they just know what the law is, perhaps due to many years of immersion in the legal culture, accumulating practical knowledge of the law. These judges may appear to have assembled legal arguments to rationalise a conclusion reached on ulterior grounds, whereas in fact they were genuinely certain that their intuitive conviction about the right legal answer was reliable, but then had to prove it.

\section{Evidence of Judicial Subterfuge}

It is possible to distinguish between different kinds of subterfuge. First there is the lie - in this context, the "white lie" or "noble lie"- which is known to be untrue and intended to deceive. Then there is the half truth, intended to deceive by deliberately failing to mention relevant qualifications. Next is the "fig leaf": a falsehood that is neither intended nor likely to deceive. A fig leaf covers something distasteful or offensive: everyone knows what is underneath, but some

21. Except in the state of Victoria and the Australian Capital Territory.

22. See G Huscroft, "Vagueness, Finiteness, and the Limits of Interpretation and Construction" in G Huscroft \& B Miller, eds, The Challenge of Originalism; Essays in Constitutional Theory (Cambridge: Cambridge University Press, 2011).

23. BN Cardozo, Selected Writings of Benjamin Nathan Cardozo ed by ME Hall (New York: Fallon, 1947) at 37 and quoted by J Brand-Ballard, Limits of Legality; The Ethics of Lawless Judging (Oxford: Oxford University Press, 2010) at 13.

24. J Frank, Law and the Modern Mind (New York,1930; Anchor Books reprint,1963) at 10 and 40-41. 
would be disturbed if directly confronted with it. It somehow preserves the decencies, without actually fooling anyone. Some statements, like euphemisms, mask uncomfortable truths whose blunt statement would be discourteous, hurtful or disturbing. Note that something can function both as a fig-leaf for those "in the know", such as lawyers, and as a noble lie that deceives more naïve or ignorant people, such as politicians or the general public. Perhaps that is an example of what is sometimes called "double-speak". ${ }^{25}$

Lawyers do sometimes suspect judges of subterfuge. They employ euphemisms to describe this, such as by saying that judges adopted a "strained" interpretation of a provision, when it was given a meaning it plainly did not have. Or they are more blunt, speaking of judicial "acrobatics" or "contortions", "tortured constructions" and so on. ${ }^{26}$ Over a century ago, Roscoe Pound devoted an entire article in the Harvard Law Review to the topic "Spurious Interpretation", which he described as "put[ting] a meaning into the text as a juggler puts coins, or what not, into a dummy's hair, to be pulled forth presently with an air of discovery". ${ }^{27}$ Legal historian G. Edward White once referred to the "conventional techniques of judicial subterfuge". ${ }^{28}$

No doubt some - perhaps most — allegations of judicial subterfuge have been wrong. But it is very unlikely that they have all been. Let me emphasise, though, that cases in which judges use subterfuge make up a tiny proportion of the cases they deal with overall.

Now let's consider some examples. It would be easy to start with American law, because there is a long tradition in that country of sceptical theories holding that judges concoct legal rationalisations for results decided in advance. Some commentators have claimed that this is common in the United States. ${ }^{29} \mathrm{I}$ doubt that, but I will make my job more difficult by starting elsewhere, with the birthplace of the common law, Britain.

\section{Britain}

Although the British legal tradition is now regarded as much more formalistic than the American one, it has a pragmatic strand that includes judicial subterfuge. ${ }^{30}$ After all, the medieval common law invented many so-called "legal fictions". These were used by courts to evade rigid procedures and forms, or extend their jurisdictions,

25. "Doublespeak", Wikipedia (as at 30 January, 2008) http://en.wikipedia.org/wiki/Doublespeak.

26. See G de Q Walker, “The Unwritten Constitution” (2002) 27 Austl J Legal Phil 144 at 154.

27. R Pound, "Spurious Interpretation" (1907) 1 Colum LR 379.

28. GE White, The American Judicial Tradition (New York: Oxford University Press, 1976) at 260.

29. R Posner, "What Do Judges and Justices Maximize? (The Same Thing Everybody Else Does)" (1993) 3 Supreme Court Econ Rev 1, 30, quoted in J Brand-Ballard, supra note 23 at 5. See also P Butler, "When Judges Lie (and When They Should)" (2007) 91 Minn LR1785 at 1786 and 1821; and MBE Smith, "Do Appellate Courts Regularly Cheat?" (1997) 16 Crim Justice Ethics 11 (the author's answer is "yes"). See also MBE Smith, "May Judges Ever Nullify the Law?" (1999) 74 Notre Dame LR1657.

30. For a comparison of British and American legal culture, see PS Atiyah and RS Summers, Form and Substance in Anglo-American Law; a Comparative Study of Legal Reasoning, Legal Theory, and Legal Institutions (Oxford: Oxford University Press,1987). 
in ways that were contrary to existing rules. ${ }^{31}$ For example, the jurisdiction of Exchequer was confined to the enforcement of obligations owed to the Crown, but the Court allowed plaintiffs to pursue ordinary debts by pleading that they owed money to the Crown but could not pay it because their creditor had not paid them. ${ }^{32}$ After a time, this form of pleading became standard and everyone knew it was a fiction. So then it was a fig-leaf, rather than a lie used to conceal the truth.

According to Lon Fuller, the author of a book about these fictions, they could be found in almost every area of law. ${ }^{33}$ They have provoked diverse reactions. Jeremy Bentham denounced them as "wilful falsehoods" and "swindles" aimed at "the stealing of legislative power" ${ }^{44}$ But Blackstone said that the end, of facilitating cautious legal change, justified the means, of using falsehood..$^{35}$

Professor A. V. Dicey thought that fictions helped the common law to subordinate the so-called "absolute prerogatives" that the Crown claimed were beyond legal scrutiny. This is now regarded as a foundational victory for the rule of law:

The fictions of the courts have in the hands of lawyers such as [Sir Edward] Coke served the cause both of justice and of freedom, and served it when it could have been defended by no other weapons.... Nothing can be more pedantic, nothing more artificial, nothing more unhistorical, than the reasoning by which Coke induced or compelled James [I] to forego the attempt to withdraw cases from the courts for his Majesty's personal determination. But no achievement of sound argument, or stroke of enlightened statesmanship, ever established a rule more essential to the very existence of the constitution than the principle enforced by the obstinacy and the fallacies of the great Chief Justice.... ${ }^{36}$

Judges have often found ways to evade laws mandating punishments they regard as excessive. One of the ancient legal fictions involved benefit of clergy, whereby clerics accused of crimes could only be tried in church courts and not in common law ones. Common law judges used this to evade a law requiring all felons to be sentenced to death, by holding that anyone who could read a psalm was deemed to be a cleric, and then extending this to illiterates who could recite a psalm. ${ }^{37} \mathrm{In}$ his History of English Criminal Law, Radzinowicz observed that the proliferation of statutes imposing capital punishment in the late eighteenth century, which was "opposed by an advanced section of public opinion", led to judges often evading them by distorting or misapplying principles of statutory interpretation. ${ }^{38}$ The judges invented a series of technicalities that "were clearly outside the contemplation of

31. LL Fuller, Legal Fictions (Stanford, CA: Stanford University Press, 1967).

32. NJ Knauer, "Legal Fictions and Juristic Truths" (2010) 23 St Thomas LR 1 at 9.

33. Fuller, supra note 31 at 1.

34. Quoted by Knauer, supra note 32 at 4 and 15 .

35. Quoted by Knauer, ibid at 14; see also PJ Smith, "New Legal Fictions" (2007) 95 Georgetown LJ 1435 at1466.

36. AV Dicey, An Introduction to the Study of the Law of the Constitution, 10th ed by ECS Wade (London: MacMillan, 1959) at 18-19.

37. JH Baker, An Introduction to English Legal History, 3rd ed (London: Butterworth, 1990) at 58689, cited in L Alexander \& E Sherwin, "Deception in Morality and Law" (2003) 22 Law \& Phil 393 at 425.

38. L Radzinowicz, A History of English Criminal Law and Its Administration from 1750, vol 1 (London: Stevens \& Sons, 1948) at 87. 
the legislature, and sometimes directly opposed to the known legislative intent." ${ }^{\prime 39}$ Judicial evasion remains today a common response to harsh or mandatory sentencing laws, as American and Australian experience shows. ${ }^{40}$

Turning to contract law, a learned author says that courts have used "a great variety of techniques" to pay lip service to contract law in theory, while ignoring it in practice. These techniques of "non-interpretation" have been used "to make contracts read 'fairly' (from the courts' point of view)". For example, "they manipulated a concept of fundamental breach" so that exclusion clauses would not gravely disadvantage a weaker party; "found collateral contracts ... that introduce different terms that the courts consider preferable to those contained in the "main contract", and "limited the scope of contracts through various devices" in order to bypass undesirable terms. "Any but the most biased and blind observer can appreciate the policy considerations lying behind the manipulations of the various techniques." 41

Supposed implications are a fertile device for judicial tampering with legal texts, whether contracts, statutes or constitutions. Sometimes implications are quite genuine: an unexpressed norm really is implied by the text and essential to its proper understanding. But it is remarkable how often lawyers use idiosyncratic legal terminology that describes terms being "implied into" or "read into" legal texts, or of judges "making implications". Or at least, this is common in Australia. Terms that are genuinely implied by a text are inferred from it: to speak of terms being implied into or read into it is to use oxymoronic expressions that, in trying to have it both ways, defy ordinary English. They presumably function as euphemisms, by blurring the distinction between the discovery of genuine implications, and the insertion of spurious ones. In the latter case, the description of it as an implication is really a fig-leaf.

Conor Gearty, Professor of Human Rights Law at the LSE, refers in a recent book to "the seduction of the well-crafted lie", and observes that "generations of judges have found themselves embracing various kinds of deception as an essential way of bridging the gap [between the law and justice]. ${ }^{\prime 42} \mathrm{He}$ goes on to discuss a number of "myths" and "fictions" whose "lubricating power" has enabled justice to be done in the teeth of uncompromising facts or logic. ${ }^{43}$ For example, he discusses "a tempting fiction drawn from the human rights field", namely, "the notion of an assumed waiver of a right in a situation where the factual evidence for the breach of the right cannot be gainsaid, but where insistence on it carries a range of inconvenient social costs." ${ }^{44}$

The now traditional judicial resistance to privative clauses - which I mentioned at the beginning — has involved subterfuge. Many commentators have claimed that

39. Ibid at 86, quoting Professor Jerome Hall.

40. For Australia, see A Freiberg, "Guerrillas in our midst? Judicial Responses to Governing the Dangerous" in M Brown \& J Pratt, Dangerous Offenders: Punishment and Social Order (London: Routledge, 2000); for the U.S., see text to note 73 below.

41. B Reiter, "The Control of Contract Power" (1981) 1 Oxford J Legal Stud 347 at 360-61.

42. C Gearty, Principles of Human Rights Adjudication (Oxford: Oxford University Press, 2004) at 175 .

43. Ibid at 175 and $192 \mathrm{ff}$.

44. Ibid at 192 . 
in a famous British case called Anisminic, ${ }^{45}$ the House of Lords used specious reasoning to circumvent Parliament's command that decisions of a statutory authority were not to be judicially reviewed. ${ }^{46}$ New Zealand Justice E.W. Thomas recommended that we candidly admit what judges do in such cases: "I know of no rule of law or logic which would make judicial disobedience more palatable simply because it is done covertly."${ }^{\text {"47 }}$ Britain's then leading administrative lawyer, Sir William Wade, observed that "the judges have proved willing to turn a blind eye to constitutional impediments for the sake of their historic policy of refusing to tolerate uncontrollable power", and added that "I support the judges in resorting to every possible argument, convincing or otherwise" in pursuing this policy. ${ }^{48}$

The so-called "ultra vires" doctrine in administrative law holds that the grounds on which judges review the decisions of the executive government are imposed by statute, implicitly if not explicitly. In other words, these grounds were not created by the judges themselves. Sir John Laws, an outspoken judge on the Court of Appeal, described this doctrine as a fig-leaf "serving to provide a façade of constitutional decency, with lip-service to the sovereign Parliament, while being out of touch with reality."${ }^{\prime 49} \mathrm{He}$ believes that the judges created many or most of the grounds of review, but tried to conceal this because they believed it to be inconsistent with the doctrine of parliamentary sovereignty. Lord Steyn of the House of Lords also described the ultra vires doctrine as a "dispensable fiction". ${ }^{50}$

These examples from administrative law are related to a broader category of cases involving presumptions of legislative intention. For centuries, the courts have said that in interpreting statutes they are guided by a presumption that Parliament does not intend to interfere with established common law rights, although this can be overcome by express words or necessary implication. The traditional justification for these presumptions is entirely consistent with parliamentary sovereignty: it is that if Parliament did intend to interfere with a right, it would have made that intention unambiguously clear. ${ }^{51}$

But it is increasingly fashionable to dismiss this justification as an artificial rationalisation or polite fiction, because (it is said) strong presumptive rules are applied even in the face of clear legislative intent to the contrary. ${ }^{52}$ Some say that the common law presumptions "no longer have anything to do with the intent of the Legislature; they are a means of controlling that intent". ${ }^{53}$ They believe that the

45. Anisminic Ltd v Foreign Compensation Commission 1969] 2 AC 147, [1969] 2 WLR 163.

46. For example, HWR Wade and CF Forsyth, Administrative Law, 7th ed (Oxford: Oxford University Press, 1994) at 737; EW Thomas, 'The Relationship of Parliament and the Courts' (2000) 5 Victoria U Wellington LR 9 at 27; E Kavanagh, Constitutional Review Under the UK Human Rights Act (Cambridge: Cambridge University Press, 2009) at $98 \mathrm{n} 39$ and 105.

47. Thomas, supra note 46 at 27.

48. Sir William Wade, Constitutional Fundamentals, revised ed (London: Stevens \& Sons, 1989) at 86.

49. Quoted by HWR Wade and CF Forsyth, Administrative Law, 9th ed (Oxford: Oxford University Press, 2004) at 39.

50. J Steyn, Democracy Through Law (Ashgate, UK: Aldershot, 2004) at 131.

51. Bropho $v$ Western Australia (1990) 171 Commonwealth L Reports 1, 18.

52. Sir Anthony Mason, "Commentary" (2002) 27 Austl J Legal Phil 172 at 175.

53. L Tremblay, "Section 7 of the Charter: Substantive Due Process" (1984) 18 UBC LR 201, 242. See also Kavanagh, Constitutional Review, supra note 46 at 335. 
courts have been stubbornly protecting cherished common law values from legislative interference. ${ }^{54}$ If so, the judges have not always been candid in deploying the presumptions in the past: they have sometimes used them as a smokescreen to conceal their disobeying Parliament. ${ }^{55}$ Ian Holloway has used terms such as "judicial legerdemain" and "curial sleight of hand" to describe judges "turn[ing] a Nelsonian eye to what would seem to be perfectly clear statements of legislative intent". ${ }^{56}$

Some judges now dismiss the whole idea of legislative intention as a "fiction". Yet those same judges still find it useful to use the term "legislative intention" in construing statutes. This may mean that they cannot avoid legislative intention because, despite their disclaimers, it does really exist and is indispensible to sensible statutory interpretation (which is my own view ${ }^{57}$ ). But if they believe that it does not exist, are they using the rhetoric of intention as a fig-leaf to conceal something else, such as their own creative rewriting of statutes? Some judges say that the notion of legislative intention is a "useful fiction". ${ }^{58}$ But what use can such a fiction have, other than to conceal the truth?

In the 19th Century, John Austin described judges changing the operation of the statute De Donis, and of the Statute of Frauds, "on the occasion of pretended applications" of them. ${ }^{59}$ Nick Barber has provided more recent examples of British courts in effect amending statutes in order to remedy injustice, while purporting to apply orthodox canons of interpretation. ${ }^{60}$ As well as discussing privative clauses, he describes the courts' resistance, throughout the first half of the twentieth century, to Parliament's attempts to confer legal immunity on trade unions for losses incurred during industrial disputes. The courts found this morally repugnant, and continually introduced new forms of common law liability to stymie statutory reforms.$^{61}$ In 1992, the House of Lords, in effect, retrospectively altered a statute so that men could be convicted of raping their wives. ${ }^{62}$ The decision was contrary to the well known intention of the enacting Parliament, only fourteen years previously, to preserve the traditional rule that marriage implied consent to sexual intercourse. As Barber points out, the court's judgment was "presented as a normal exercise in statutory construction", with no acknowledgement that it was really amending the statute contrary to constitutional orthodoxy. ${ }^{63}$

Patrick Devlin's book "The Judge", written after he had retired from the Court of Appeal, includes a chapter titled "The Judge and the Aequum et Bonum". This

54. J Burrows, "The Changing Approach to the Interpretation of Statutes" (2002) 33 Victoria U Wellington LR 981 at 982-83, 990-95 and 997-98.

55. Kavanagh, supra note 46 at 334-35.

56. I Holloway, Natural Justice and the High Court of Australia (Ashgate, UK: Aldershot, 2002) at 251,259, 252 and 253.

57. J Goldsworthy, Parliamentary Sovereignty, Contemporary Debates (Cambridge: Cambridge University Press, Cambridge, 2010) at ch 9.

58. Eastman v R (2000) 203 Commonwealth L Reports 1, 46 per McHugh J.

59. J Austin, supra note 14 at 635.

60. N Barber, "Sovereignty Re-examined: The Courts, Parliament, and Statutes" (2000) 20 Oxford J Legal Stud 131 at $145-49$.

61. Ibid at 148 .

62. $R \vee R[1992] 1$ AC 599 .

63. Barber, supra note 60 at 146-47. 
expression presumably comes from the Latim maxim "Bonum judex secundum aequum et bonum judicat, et aequitatem stricto juri praefert", which means "A good judge decides according to justice and right, and prefers equity to strict law". Here is some of what Devlin said:

[L]awyers perforce accept the distinction between justice according to law and justice on the merits, or ex aequo et bono as they call it ... We have to accept that every now and again, but fortunately quite rarely, a judge is confronted with having to deliver a judgment that seems to him ... to contain too much law and not enough justice. When that happens there is a temptation to alter the mixture a little... . [F]rom the earliest times the English legal system has accommodated various devices designed to enmesh the legal result with the justice of the case.... Stretching the law or moulding the facts to fit the law is the time-honoured method by which the judge consciously or unconsciously_probably half-consciously, and not permitting himself too acute an analysis - makes room for the aequum et bonum... . At all judicial levels in all judicial systems the law is sometimes stretched, a little shamefacedly perhaps. ${ }^{64}$

Noting that "it is a condition of the use of this and of all other methods and devices having the same object that the object should not be admitted", Devlin asks why the courts do not frankly admit what they do in such cases.$^{65} \mathrm{He}$ explains that would be contrary to accepted constitutional orthodoxy, settled in the seventeenth century, which denies the existence of any power to dispense with the operation of a statute. Therefore "the judge cannot openly dispense. But he can stealthily stretch or mould." 66

In the 1990s, political scientist David Robertson interviewed all the then Law Lords while researching his book Judicial Discretion in the House of Lords. ${ }^{67} \mathrm{He}$ reported that in "most" of these interviews, the judges spoke about "cheating": reaching decisions that violate the constraints imposed by accepted canons of legal reasoning. Many accused Lord Denning of cheating, and some criticised their current colleagues: for example, "I dissented because the majority were cheating". They described their inner sense of obligation by saying "one tries not to cheat", but made concessions such as "Perhaps I cheated a little bit in X v. Y" ${ }^{68}$ They indicated a strong belief that such cheating is rare, although Robertson concluded that it was seldom necessary because the indeterminacy of the law gave them such extensive discretion. ${ }^{69}$

Sometimes these tensions find expression in reported judgments. In Duport Steels Ltd v. Sirs, Lord Diplock criticised the Court of Appeal (led by Denning) for "invent[ing] fancied ambiguities as an excuse for failing to give effect to [the] plain meaning [of a statute] because they themselves consider[ed] that the consequences of doing so would be inexpedient, or even unjust or immoral." ${ }^{.70}$ Lord

64. P Devlin, The Judge (Oxford: Oxford University Press, 1979) at 84, 86, 90, 92.

65. Ibid at 90 .

66. Ibid at 91 .

67. D Robertson, Judicial Discretion in the House of Lords (Oxford: Clarendon Press, 1998) at viii.

68. Ibid at 17 and 74 .

69. Ibid at 75 .

70. [1980] 1 WLR 142, 157. 
Scarman alleged that "in their desire to do justice the court [of Appeal] failed to do justice according to law." ${ }^{\text {71 }}$

That is an overview of judicial subterfuge in Britain. I could provide many examples from other jurisdictions, especially (as I said before) the United States. Many would be similar. For example, leading scholars have argued that American judges have often "updated" statutes, to bring them into line with contemporary values, while pretending to follow orthodox interpretive techniques concerned with clarifying the legislature's original intent. ${ }^{72}$ Surreptitious judicial evasion of mandatory sentencing laws and capital punishment has also been reported in the American literature, as has allegedly routine evasion of the rule excluding unlawfully obtained evidence. ${ }^{73}$ Decisions on federal jurisdiction have attracted charges of disingenuousness or subterfuge. ${ }^{74}$ The major difference, given that Britain has no written constitution, concerns constitutional law. Many alleged examples of judicial subterfuge, not only over the last half century but well before that, involve the Supreme Court wilfully reading its own notions of justice and human rights into the Constitution. The critics of "judicial activism" have not always been motivated by political opposition to its results. ${ }^{75}$ For example, John Hart Ely-a noted liberalaccused the Supreme Court in Roe v. Wade, the famous abortion case, of "indulging in [a] sheer act of will, ramming its personal preferences down the country's throat." ${ }^{\text {} 76}$ Court of Appeals judge Richard Posner refers to

the considerable disingenuousness of many of the judicial opinions that [are] most admired, such as Brown v. Board of Education... . If utter candor is a duty of judges as of no other public officials and if disingenuous judicial opinions are illegitimate, we have had a crisis of judicial legitimacy since Marbury v. Madison. ${ }^{77}$

Many examples, like the Kirk case that I started with, involve judges bolstering their own independence and authority to review the activities of the political branches of government. They involve, in other words, judges using subterfuge to protect what they think is essential to preserving the rule of law.

It is widely believed that Chief Justice John Marshall lied in the famous American case of Marbury v. Madison, in which the doctrine of judicial review of legislation was firmly established for the first time. It is not that he lied about that doctrine; rather, the claim is that he lied about the meaning of a statute, by adopting an absurd interpretation of it, in order to raise the question of judicial review. ${ }^{78}$ Even some people on the left agree that a number of egregious mistakes

71. Ibid at 168 .

72. See N Zeppos, "Judicial Candour and Statutory Interpretation" (1989) 78 Georgetown LJ 353, especially at $358,361,363,378$.

73. Butler, supra note 23 at 1794-98, 1802-03, and 1808.

74. LE Little, "Hiding With Words: Obfuscation, Avoidance, and Federal Jurisdiction Opinions" (1998) 46 UCLA LR 75; FM Bloom, "Jurisdiction's Noble Lie" (2009) 61 Stanford LR 971.

75. Brand-Ballard, supra note 23 at 81.

76. JH Ely, "The Wages of Crying Wolf” (1973) 82 Yale LJ 920 at 944.

77. Ibid at 350-51. Brown was a focus of criticism in Herbert Wechsler's famous article "Towards Neutral Principles of Constitutional Law" (1959) 73 Harv LR 1.

78. R Bork, The Tempting of America, The Political Seduction of the Law (New York: Touchstone Books, 1990) at 22-24. 
in Marshall's reasoning border on the fraudulent. ${ }^{79}$ Yet most commentators praise the judgment as a masterpiece of shrewd political statesmanship, which justifies its reputation for "greatness".

The decision of the Supreme Court in Bush v. Gore, which put a stop to the voting recount in Florida and confirmed George W Bush as President, was savagely criticised by leading scholars who alleged intellectual dishonesty on the part of the Republican-appointed majority Justices. According to some, this was for an ignoble rather than a noble cause, involving blatant political partisanship. ${ }^{80} \mathrm{But}$ other critics were more generous. David Strauss suggested that, arguably, the Court "deliberately acted in a way that could not be legally justified, in order to prevent some greater harm". ${ }^{81}$ There are two 'greater harms' that the Court might have thought (whether rightly or wrongly) that it needed to prevent, namely, terminating an escalating and dangerously destabilising constitutional crisis, and preventing the Democrat-dominated Florida Supreme Court from manipulating the law to help Al Gore win the election. Note that both of these objectives relate to preserving the rule of law: in the latter case, the higher court violates the law in order to prevent a lower court from doing so.

Turning to Australia, the courts' most blatantly "inventive" decisions have often been designed to shore up judicial authority or independence. Australian judges have used the same tactics as their British counterparts to evade privative clauses. The pretended use of orthodox interpretive techniques for this end has been described by leading commentators as "an exercise in sophistry" 82 and as "disingenuous disobedience" of the will of Parliament. ${ }^{83}$ In constitutional law, the High Court first began to construct a doctrine requiring the strict separation of judicial power in a case where it was contrary both to the constitutional text and clear evidence of the framers' intentions ${ }^{84}$ More recently, the Court partially extended this doctrine to most state courts, although this was inconsistent both with previous authority and strong disapproval voiced in previous cases of "free standing" unexpressed principles, enforced independently of the written provisions from which they were supposedly inferred. ${ }^{85}$ This was in a case called Kable, whose reasoning the late Professor George Winterton — a universally respected authority— described as "barely even plausible" ${ }^{86}$ The latest step is the even more radical invention in Kirk, the case on privative clauses that I started with. ${ }^{87}$

79. See Levinson, supra note 11 at 7, 20-21, and S Sherry, "The Intellectual Background of Marbury v Madison" in M Tushnet, ed, Arguing Marbury v Madison” (Stanford, CA: Stanford University Press, 2005) at 47, 49 and footnotes.

80. See the views of Geoffrey Stone, quoted in Levinson, supra note 11 at 14-15.

81. DA Strauss, "Bush v Gore: What Were They Thinking?" (2001) 68 U Chicago LR 737 at 739.

82. C Saunders, "Plaintiff S157: A case-study in common law constitutionalism" (2005) 12 Austl J Admin Law 115 at 117 (she actually says that "at first glance" it is an exercise in sophistry, because it can be defended on two grounds; but she goes on to reject both of them).

83. M Aronson, B Dyer \& M Groves, Judicial Review of Administrative Action, 3rd ed (Sydney, AU: Lawbook Co, 2004) at 830.

84. J Goldsworthy, "Australia: Devotion to Legalism" in J Goldsworthy, ed, Interpreting Constitutions (Oxford: Oxford University Press, 2006) at 125-26, 128-29.

85. Ibid at 148-49.

86. G Winterton, "Justice Kirby's Coda in Durham Holdings” (2002) 13 Pub LR 165-70.

87. Kirk v Industrial Relations Commission of NSW (2010) 239 CLR 531. 
Canadian courts have not been immune to allegations of result-oriented judicial subterfuge. In rule of law cases, the Privy Council before 1949 and, later, the Supreme Court, struck down laws granting judicial power to administrative tribunals, although according to Professor Peter Hogg, "the basis for the decisions was unclear or implausible." ${ }^{88}$ In 1997, again according to Hogg, the Supreme Court invoked an "unwritten principle" of the independence of provincial judges, and proceeded to construct "an elaborate edifice of doctrine with little or no basis in the text." ${ }^{89}$ I once described the reasoning in that case as so plainly contrived that it could not be explained "as anything other than a disingenuous rationalization of a result strongly desired by the judges on policy grounds." ${ }^{90}$

I will finish this list of examples with one from India. The Indian Supreme Court interpreted a provision requiring the President to consult with the Chief Justice before appointing new puisne justices to the Court, as requiring that the Chief Justice's advice be followed, and it later added a requirement with no textual support whatsoever, that the Chief Justice must consult with his four most senior colleagues before tendering that advice. ${ }^{91}$ The Court wanted to avoid being stacked for political purposes, without giving the Chief Justice too much power. These were both no doubt worthy goals, but the provision plainly did not mean what the Court said it meant, whether the word "consult" is understood in its ordinary sense or in the historical context of its enactment.

I now turn to reflect on these examples.

\section{Well-meaning Sloppy Thinking}

Is there an alternative to subterfuge that can achieve the same results? "Seinfeld" fans will remember an episode in which George, supposedly an expert liar, is asked to coach Jerry in the art of lying. He says: "Jerry, just remember, it's not a lie if you believe it." ${ }^{92}$ Judges must lie about the law only if they know that rigorous argument would demonstrate that their preferred conclusion is not logically open to them. If rigorous argument is not pursued - if concepts are left conveniently fuzzy, and inferences sufficiently loose and slippery - then they can reach a pragmatically desirable conclusion with a clear conscience. That may be why Lord Devlin said that the timehonoured method by which a judge can do justice is to stretch the law, although "probably half-consciously, and not permitting himself too acute an analysis." ${ }^{\prime 93}$ This was described by another English judge as "well-meaning sloppiness of thought." 94

88. Goldsworthy, Interpreting Constitutions, supra note 84 at 73.

89. Ibid at 74 .

90. J Goldsworthy, "The Preamble, Judicial Independence and Judicial Integrity" (2000) 11 Constitutional Forum 60.

91. SP Gupta v India AIR 1982 SC 149, (1981) Supp SCC 87; Supreme Court Advocates on Record Association v India AIR 1994 SC 268, (1993) 4 SCC 441; discussed in J Goldsworthy, Interpreting Constitutions, supra note 84 at 259-61.

92. "The Beard", Seinfeld, Season 6, Episode 16 (1995).

93. $P$ Devlin, The Judge, supra note 64, 90 [emphasis added].

94. P Freund, "Foreword" in D Shapiro, ed, The Evolution of a Judicial Philosophy: Selected Opinions and Papers of Justice John M Harlan (Cambridge, MA: Harvard University Press, 1969) at xiv, quoted by DL Shapiro, "In Defense of Judicial Candor" (1987) 100 Harv LR 731 at 740. 
The popular impression of legal thinking is that it is logically rigorous. But legal reasoning, whether of judges, advocates or legal scholars, rarely has the clarity and rigour of the best analytical philosophy. Often this is because the subject-matter is simply incapable of being treated as rigorously. But more importantly, legal reasoning in real cases leads to practical decisions that have drastic effects on individual's lives or the welfare of the community, for which judges properly feel some moral responsibility. Consequently, legal reasoning can have a tendentiousness - an almost palpable gravitation towards a desired conclusion - that is lacking in the work of analytical philosophers, pure mathematicians or nuclear physicists.

It is doubtful that well-meaning sloppy thinking can form a category independent of others I have mentioned. If it is really sincere, with no intent to deceive, then it is an example of wishful thinking..$^{95}$ If it is insincere, and intended to deceive, it is a kind of subterfuge. A conscious choice not to pursue empirical enquiry or logical analysis to the usual extent is a kind of intellectual dishonesty, although perhaps dishonesty can be negligent or reckless as well as intentional. To the extent that subterfuge is involved, we must consider the arguments for and against intellectual honesty in judicial reasoning.

\section{Arguments Justifying Judicial Subterfuge}

Almost everyone agrees that lying may sometimes be morally justified. There are a number of philosophical books devoted to the subject. ${ }^{96}$ At the very least, if violence is sometimes justified to save life and liberty — as all but pacifists acceptthen surely lying must be as well.

Legal philosophers agree that in some circumstances judges might be morally justified in lying about the law. That is a standard response of legal positivists to natural law critiques. When natural lawyers accuse legal positivists of requiring judges to apply evil laws, the positivists reply that a judge's legal obligation to apply the law might be outweighed by a moral obligation not to do so. Judges should not willingly collude in extreme injustice, even if they must lie to avert it. The literature usually discusses three ways by which a positivist judge can avoid this (without undergoing a damascene conversion to some kind of natural law theory): (1) forthright defiance, which might lead to sanctions including the judge's dismissal and/or punishment; (2) resignation; and (3) furtive disobedience concealed by a spurious and insincere legal rationalisation. ${ }^{97}$

If the first two options lead to the disapproving judge leaving office, and being replaced by a more compliant one, then the injustice will not be avoided or remedied. Option two, resignation, is vulnerable to criticism as a cop-out: the judge keeps

95. See text to notes 23-24 above.

96. E.g., S Bok, Lying: Moral Choice in Public and Private Life (1978); D Nyberg, The Varnished Truth: Truthtelling and Deceiving in Ordinary Life (Chicago, IL: University of Chicago Press, 1993); C Martin, ed, The Philosophy of Deception (Oxford: Oxford University Press, 2009); TL Carson, Lying and Deception; Theory and Practice (New York: Oxford University Press, 2010).

97. See Butler, supra note 29 at 1785. On lying, see R Dworkin, Taking Rights Seriously (Cambridge, MA: Harvard University Press, 1978) at 327. 
his or her hands clean, but the victim suffers injustice anyway. ${ }^{98}$ That leaves the third option, subterfuge - or as the title of a recent American discussion of the phenomenon put it, "To Do a Great Right, Do a Little Wrong". ${ }^{99}$

In countries where injustice, oppression and corruption are prevalent, the judicial noble lie might be justified more often than elsewhere. That is why the debate between natural lawyers and legal positivists has focused on the predicament of judges in regimes such as Nazi Germany, apartheid South Africa, and American states affected by slavery before the civil war. Also, in a country where democracy, the rule of law or a new constitution is not yet firmly established, judges might have to take more liberties in order to ensure that these institutions take firm root. Robert Bork offers this by way of justification for Chief Justice Marshall's alleged sleight of hand in Marbury v. Madison. ${ }^{100}$ And some of the extraordinary decisions of the Indian Supreme Court might be justified on this basis. If there was a real danger of politicians stacking the bench with cronies or hacks, in order to bend the law to their will, then the Supreme Court may have been morally justified in holdingcontrary to law - that the requirement that the President "consult" with the Chief Justice meant that he had to obey the Chief Justice in appointing new judges to the Court. ${ }^{101}$

If we accept that there is no absolute moral prohibition of judicial subterfugethat it may, in some circumstances, be morally justified - then it becomes a question of degree. How often is it justified in modern western democracies? There is a growing body of literature in American law journals devoted to the topic of "judicial candour", discussing whether or not judges should always be completely frank in setting out the reasons that actually motivated them to reach their decisions. ${ }^{102}$ The authors usually recommend candour except in extreme cases. ${ }^{103}$ We tend to think that in countries like ours, gross violations of human rights or the rule of law are rare. But the occasional "extreme case" might arise. An Australian academic recently defended what he called "legal acrobatics" by the High Court on the ground that the circumstances were "extreme", and a "civilised result" could not be achieved in any other way. ${ }^{104}$

In a just published book, Limits of Legalism, The Ethics of Lawless Judging, the philosopher Jeffrey Brand-Ballard advocates that judges resort more frequently to furtive deviations from the law, to avoid not only extreme but even moderate injustice. ${ }^{105}$ His book offers an unorthodox defence of judicial activism. Most defenders insist that decisions attacked as activist are legally respectable, and dismiss the

98. Butler, supra note 29 at 1811.

99. W Farnsworth, “'To Do a Great Right, So a Little Wrong': A User's Guide to Judicial Lawlessness" (2001) 86 Minn LR 227.

100. Bork, supra note 78 at $27-28$.

101. See text to note 91 above.

102. E.g., DL Shapiro, "In Defence of Judicial Candor" (1987) 100 Harv LR 731; SC Idleman, "A Prudential Theory of Judicial Candor" (1995) 73 Texas LR 1307, JJ Kircher, "Judicial Candor: Do As We Say, Not As We Do" (1990) 73 Marquette LR 421, and S Altman, "Beyond Candor" (1990) 89 Michigan LR 296.

103. Butler, supra note 29 at $1817-18$.

104. G de Q Walker, “The Unwritten Constitution” (2002) 27 Austl J Legal Phil 144 at 154.

105. Brand-Ballard, supra note 23 , especially $271-80$. 
opposite view as politically motivated; whereas Brand-Ballard is prepared to defend such decisions even if they are, as he puts it, lawless. ${ }^{106}$

\section{Arguments against Judicial Subterfuge}

I strongly incline to the view that covert judicial law-breaking may (and perhaps, in some circumstances, must) be resorted to only in very extreme cases. ${ }^{107} \mathrm{I}$ do not have any original arguments for this position. The standard ones include the following.

An essential function of law, called the "settlement function", is to provide a generally accepted, authoritative method of settling disputes that might otherwise be intractable. ${ }^{108}$ These include disputes about morality. People often have disagreements about what is morally right or wrong that will never be resolved. We need, as a community, to make collective decisions about these contested issues, and so we need decision-making procedures whose outcomes will be accepted as binding even by those who continue to disagree about their merits. If these procedures are democratic, they provide the fairest method of decision-making, which reinforces the obligation to respect their outcomes. If those outcomes are not generally respected - if those who disagree with their merits refuse to comply with themthen we remain where we started, in a predicament of perpetual disagreement and potential if not actual conflict.

The role of judges includes enforcing those outcomes even if they disagree with their merits. If judges did not generally do this, they would set a dangerous example for the rest of the community, including the other branches of government. If judges are not prepared to obey collective decisions they disagree with, why should anyone else? Attempts by the judges to conceal their disobedience by subterfuge are likely to fail-their published reasoning is very carefully scrutinized by lawyers, academics, and other officials. The calculations that judges would need to make, if they followed Brand-Ballard's recommendations and had to assess the likely consequences of more frequent but strategic subterfuge, are too difficult to be practicable. And would we really want judges to be making such calculations behind closed doors - asking themselves just how much subterfuge they can get away with? Lying violates the trust that is essential to harmonious social intercourse, and its exposure is likely to breed cynicism and loss of respect for the judiciary. Judges, who are honest people, may also suffer some psychological damage from lying. Moreover, the historical record shows that there is no guarantee that judges' value judgments, or their predictions of practical consequences, are any more reliable than anyone else's.

On the other hand - and there always is another hand - if judicial subterfuge is confined to remedying obvious and extreme cases of injustice or breaches of

106. See ibid 94-95 and 272-73, discussing Griswold v Connecticut (1965) 381 US 479.

107. I am indebted for several of the following ideas to Jim Evans, formerly Professor of Law at the University of Auckland, email dated 11 February 2007 (on file with author).

108. See Larry Alexander \& Emily Sherwin, The Rule of Rules: Morality, Rules and the Dilemmas of Law (Durham, NC: Duke University Press, 2001) at 11-25. 
the rule of law, its exposure might not damage trust in the judiciary or breed cynicism. Indeed, knowledge that judges occasionally act in this way might strengthen public confidence in them. Patrick Devlin observed that "The judicial qualities which the public singles out for praise are common sense and humanity; devotion to the law is less admired than a willingness to strain it." ${ }^{109}$ We do not need to speculate about this in the abstract - there is historical experience we can learn from. If I am right, legal history shows that there have always been a small number of cases in which judges have used subterfuge to promote their conception of justice and good governance. Yet the judiciary has not succumbed to rampant lawlessness, nor has the rule of law collapsed. It may, indeed, have sometimes been strengthened - as Dicey said about the fabrications of Sir Edward Coke. ${ }^{110}$ When, in cases like Kirk that I started with, the legal profession heartily approves of the stance taken by the judiciary, and turns a blind eye to any subterfuge involved, damage to public confidence in the judiciary seems unlikely.

\section{The Role of the Legal Scholar}

I will conclude with some observations about the role of scholars and teachers of law. If in a rare case a judicial lie is justified, because of its beneficial consequences, is it our duty as scholars and teachers not to expose the lie, or even to aid and abet it by adding the authority of our learning to its specious rationalisation? Imagine, for example, that I was an academic in India, and I accepted that the danger of politicians stacking the bench for nefarious purposes was sufficient to justify the Supreme Court's "noble lie" about the constitutional requirements for judicial appointments. ${ }^{11}$ Presumably I would regard myself as morally bound not to expose the lie. Why not, if the judges were justified in lying in the first place?

But if I were prepared to do this, would I surrender the right to object to other decisions on the sole ground that they were not legally justified? Would my disagreements with judicial reasoning then always depend partly on whether or not I like the results, and not just on whether I agree with the legal reasoning? Would I always have to address the moral or political merits of a decision, as well as the legal merits? If so, legal scholarship would become much messier and more difficult. Instead of just considering what the law requires (which can be difficult enough), it would always be necessary in addition to consider whether the law should be followed. Law would lose its "settlement function" for scholars as well as for everyone else: legal reasoning by itself would never settle anything, and we would always have to fall back on moral and political argument.

But I do not think that this would follow, provided that it is reasonable to adopt a general working assumption that judges should adhere strictly to the law, which can be overridden only in cases of extreme injustice. That assumption could then underpin legal reasoning and debate in almost all cases.

109. Devlin, supra note 64 at 86.

110. See Dicey's observations about Sir Edward Coke, text to note 36 above.

111. See text to note 91 above. 
Here are some other worries about the role of legal scholars. The usual role of the scholar in any University discipline is to shine the light of reason and truth on the field of study in question. It is to think as deeply, rigorously, clearly, and consistently as possible, and to remove confusion and obfuscation from thought. Many legal scholars see their mission in that light, and demand much the same of judges. Alexander Bickel once said that "the explication of [legal] principle is disciplined, imposing standards of analytical candor, rigor, and clarity. The ... [task] is to reason, not feel, to explain and justify principles ... to the last possible rational decimal point." ${ }^{12}$

In law, as in other disciplines, depth, rigour, clarity and consistency have the effect of channelling and constraining reasoning - they reduce or eliminate indeterminacies, and close off options that might otherwise appear to be open. As logic is pursued more thoroughly and deeply, the scope for legitimate judicial discretion is reduced. But is this necessarily a good thing? Can logic be pressed too far? Can depth, rigour, clarity and consistency sometimes be enemies of good, progressive decision-making?

One of the differences between scientific and legal thought is that in the sciences, reasoning that is logically flawed or factually inaccurate will usually fail the test of practical implementation. This can have disastrous consequences, such as buildings collapsing and aeroplanes falling from the sky. On the other hand, reasoning that purports to elucidate existing law can be inaccurate or logically flawed yet have beneficial consequences when put into practice.

It is all very well for academics, in the tranquillity of their ivory tower, with no responsibility for making decisions that have an immediate, practical impact, to insist on a strict application of the conclusions of logically rigorous legal reasoning. But for those sitting in the seat of judgment, facing fellow human beings whose fate lies in their hands, perhaps logic should sometimes defer to compassion. Ralph Waldo Emerson may have been right to say that "A foolish consistency is the hobgoblin of little minds." 113

Law is often said to be a matter of practical wisdom rather than cold, intellectual analysis. Does practical wisdom sometimes counsel us to rein in our pursuit of logic, to blunt the cutting edge of analysis, so that we can reach (or allow other people to reach) decisions that from a logical point of view might not withstand too close a scrutiny?

The patron saint of pragmatism in American legal theory, Oliver Wendell Holmes Jr., famously said:

the life of the law has not been logic, it has been experience. The felt necessities of the time, the prevalent moral and political theories, intuitions of public policy, avowed or unconscious, and even the prejudices which judges share with their fellow-men, have had a good deal more to do than syllogism in determining the rules by which men should be governed. ${ }^{114}$

112. A Bickel, The Morality of Consent (New Haven, CT: Yale University Press, 1975) at 26.

113. "Self-Reliance" in Essays, First Series (1841) available at http://ebooks.adelaide.edu.au/e/emerson/ ralph_waldo/e53e/part2.html.

114. OW Holmes, The Common Law (Boston, MA: Little Brown,1881) at 1. 
This suggests that law evolves to better serve the needs of a changing society if judges are often guided more by pragmatic considerations than by logical ones. Holmes was talking about the common law, with respect to which his aphorism is now uncontroversial, but I am asking whether it can be generalised to apply to statute law and constitutional law as well. ${ }^{115}$

But this must put legal scholars in an awkward position. For a start, we have an obligation to teach our students how the law really works, including how judicial subterfuge forms part (even if just a tiny part) of judicial practice, so that the students are better equipped to serve their future clients. The students have to be taught that strict legal logic can always, potentially, be trumped by a "wild card" consisting of an appeal to the judges' views of justice or good governance.

Moreover, how can we know when to pull our punches - to tone down logical rigour, clarity, depth and consistency? For me, the "worst case" scenario is this: perhaps the special qualities scholars like me think we have to contribute to the legal profession - the ability, the specialised expertise, and the time for reflection that rigorous analysis requires - are sometimes not only superfluous, but positively unwelcome.

Logic cannot be thrown out of the window altogether: we surely want judges to be constrained by law in most cases. It would not be pragmatically desirable if they felt free to decide legal disputes however they think best regardless of legal norms. But perhaps what is required is a compromise. Perhaps the best way to achieve that compromise is to leave legal reasoning to busy, practical peoplebarristers and judges - who have enough time to be guided by logic to some extent, but not so much time that they end up being constrained by an excess of logic, unduly tying the judges' hands. If so, then perhaps carping academics like me are just an impediment to progressive legal evolution. Perhaps everyone would be better off if we just shut up and let busy practitioners get on with it, the result being a healthier mix of less relentless logic and more pragmatically driven legal evolution.

But on reflection, I think this is fallacious. Even if judges should sometimes subordinate legal logic to other values, logic is still an essential part of the mix, crucial to ensuring that judges do not stray too far or too often. As Lord Devlin once said, "The common law is tolerant of much illogicality, especially on the surface; but no system of law can be workable if it has not got logic at the root of it." 116 So the scholar committed to logical rigour plays a vital role in the system, even if logic is not always decisive. Justice Antonin Scalia once called himself a "fainthearted originalist". ${ }^{117}$ Perhaps I am becoming a "faint-hearted legalist".

I will end by quoting Ronald Dworkin:

115. Note that Holmes may not have been consistent. According to Judge Learned Hand, when he once admonished Holmes to "do justice", Holmes replied: "That is not my job. My job is to play the game according to the rules." L Hand, "A Personal Confession" in The Spirit of Liberty, 3nd ed by Irving Dilliard (New York: Vintage Books, 1960) 302, 306-07. For discussion, see M Herz, " Do Justice!' Variations on a Thrice Told Tale" (1996) 82 Virginia LR 111. But if "experience" can trump "logic", it is not clear why it cannot enable "justice" to trump "the rules".

116. Hedley Byrne \& Co Ltd v Heller [1964] AC 465, 516.

117. A Scalia, “Originalism: The Lesser Evil" (1989) 57 U Cin LR 849 at 864. 
Judges do not gain legitimacy from God or election or the will of the governed or their supposed pragmatic skill or inspired reasonableness. The sole ground of their legitimacy - the sole ground - is the discipline of argument: Their institutional commitment to do nothing that they are not prepared to justify through arguments that satisfy, at once, two basic conditions. The first is sincerity. They must themselves believe, after searching self-examination, that these arguments justify what they do, and they must stand ready to do what the arguments justify in later, perhaps very different, cases as well, when their own personal preferences or politics are differently engaged. The second condition is transparency. The arguments they themselves find convincing must be exactly the arguments they present to the professional and lay public in their opinions, in as much detail as is necessary to allow that public to judge the adequacy and future promise of those arguments for themselves. ${ }^{118}$

In this lecture, I have queried the absoluteness of this admirable statement of principle, and asked whether it might be subject to exceptions. ${ }^{119}$

118. R Dworkin, A Badly Flawed Election; Debating Bush v Gore, The Supreme Court and American Democracy (New York: New Press, 2002) at 54-55.

119. To be fair, Dworkin himself acknowledges elsewhere that judges might sometimes be morally justified in lying about the law: see text for note 20 above. 